\title{
The Influence of Organizational Culture on Increasing Employee Motivation in Sumut Bank of Sharia Unit, North Sumatera
}

\author{
Nur M Ridha Tarigan ${ }^{1}$, Supar Wasesa ${ }^{2}$ \\ 1,2Universitas Islam Sumatera Utara, Medan, Indonesia \\ Email: nur.mridha@fe.uisu.ac.id
}

\begin{abstract}
:
This study wants to describe the influence of organizational culture on increasing employee motivation in Sumut Bank of sharia unit, North Sumatera. This research uses descriptive and verification methods. The place of research was conducted at Sumut Bank of Sharia Unit in North Sumatera. Considering the nature of this research is descriptive and verification, the research method used is descriptive survey and explanatory survey method. The type of investigation in this research is causality, which is testing the causal relationship between independent variables, intervening variables, moderating variables and dependent variables. The unit of analysis in this study is the employees at the North Sumatra Syariah Unit Bank in North Sumatra. The result shows that Organizational Culture on Increasing Employee Motivation in Sumut Bank of Sharia Unit, North Sumaterais perceived as less powerful to very strong. The highest average value on management indicators supports strengthening organizational culture, meaning that management always improves organizational culture as a support of the company's goals.
\end{abstract}

Keywords:

organizational culture; employee motivation; Sumut Bank; sharia unit

\section{Introduction}

The phenomenon of the development of Islamic financial institutions opens the eyes of the government to participate fully in the development of Islamic financial institutions with the enactment of:

- Law No. 7 of 1992 concerning banking.

- Law of the Republic of Indonesia Number 10 of 1998 concerning Amendment to Law Number 7 of 1992 concerning Banking

- Law of the Republic of Indonesia No. 21 of 2008 concerning Islamic Banking

- Bank Indonesia Regulation No. 13/13 / PBI / 2013 concerning Islamic Commercial Banks.

- Bank Indonesia Regulation No. 15/14 / PBI / 2013 concerning Sharia Business Units.

The activities of Sharia Banks in carrying out the banking process are providing funds in the form of financing. Financing / financing is an activity to release funds to support investments that have been planned, carried out alone or carried out with other people. The types of sharia financing according to the objectives are divided into sharia working capital financing, sharia investment financing, and sharia consumptive financing. Covenants or principles that form the basis of Sharia Bank operations in channeling financing are divided into 4 types, namely the principle of buying and selling (murabahah, salam and istishna), profit sharing principles (mudharabah and musyarakah), rental principles (ijarah and ijarah vomhiyah bittamlik), and complementary contracts (hiwalah, rahn, qardh, wakalah, and kafalah). Based on Bank Indonesia statistics, the main patterns of financing that dominate in Islamic banks are 


\section{Britain International of Humanities and Social Sciences (BIoHS) Journal \\ ISSN: 2685-3868(Online), 2685-1989(Print) \\ Vol. 2, No. 2, June 2020, Page: 440-449}

the principle of buying and selling and the principle of profit sharing.

Islamic banking is a bank institution that is managed with Islamic principles. The presence or establishment of Islamic banking, should depart from objective conditions with the existence of the people's decision or economic demands. Then, for an Islamic bank to survive and develop, its institutional management must be credible and the implementation of its business activities must be professional. The development of Islamic banks in Indonesia, of course, there must be support from quality human resource management. Because, it is not possible for a sharia bank to achieve success without qualified HR management.

One of the factors that influence the increase in employee motivation at the North Sumatra Bank Syariah Unit, North Sumatra is organizational culture. This is consistent with the opinion of Robbins and Coulter (2010) Organizational culture is the values, principles, traditions and ways of working shared by members of the organization and influences the way they act. In most organizations, these shared values and practices have developed rapidly along with the times and really greatly influence how an organization is run, and Ivancevich (2011) agrees, "That an organization is able to operate in an efficient only when there is shared value among employees. Values are effective desires, awareness, or desires that guide behavior ".

Based on the results of the pre-survey conducted by researchers by distributing questionnaires to 20 employees. The pre-survey results related to organizational culture are shown in Table 1.

Table 1. Organizational Culture of Bank Sumut Syariah Employees Statement Excellent Good Poor Bad Worst Total

\begin{tabular}{|c|c|c|c|c|c|c|}
\hline Statement & Excellent & Good & Poor & Bad & Worst & Total \\
\hline Individual initiative & 2 & 5 & 8 & 5 & 0 & 20 \\
\hline $\begin{array}{c}\text { Tolerance of risk } \\
\begin{array}{c}\text { Organization } \\
\text { direction }\end{array}\end{array}$ & 2 & 2 & 10 & 4 & 2 & 20 \\
\hline $\begin{array}{c}\text { Management } \\
\text { support }\end{array}$ & 2 & 3 & 8 & 4 & 1 & 20 \\
\hline Reward system & 3 & 4 & 11 & 2 & 0 & 20 \\
\hline Personal identity & 1 & 3 & 8 & 6 & 3 & 20 \\
\hline Supervision & 2 & 4 & 9 & 3 & 2 & 20 \\
\hline Frequency & 15 & 25 & 64 & 28 & 9 & 140 \\
\hline Score & 45 & 100 & 192 & 56 & 9 & 402 \\
\hline Percentage & $11,19 \%$ & $24,88 \%$ & $47,76 \%$ & $13,93 \%$ & $2,24 \%$ & $100,00 \%$ \\
\hline Average & & & & & & 2,87 \\
\hline
\end{tabular}

Source: Data processed from the questionnaire (2017)

From the data in Table 1, it shows that the average results of the questionnaire are 2.87, if referring to the interpretation of the assessment criteria of organizational culture in the North Sumatra Sharia Unit of the North Sumatra province included in the "poor" category. Based on the description above, the authors are interested in conducting more in-depth 
research on the issue with the title of research: The Effect of Organizational Culture on Increasing Employee Motivation at the North Sumatra Sharia Unit Bank, North Sumatra. "(Survey on North Sumatra Sharia Unit of North Sumatra Province).

\section{Review of Literatures}

\subsection{Organizational Theory}

According to Robbins (2007), "Organization is a system consisting of a pattern of collaborative activities carried out regularly and repeatedly by a group of people to achieve a goal".

Griffin (2004) states that an organization is a group of people who work together in a structured and coordinated way to achieve a set of goals. Therefore, organizations have a very important role in human life, so how organizations operate and are managed properly and correctly must be understood in order to achieve the expected goals. Furthermore Sondang Siagian (2005) argues that "organization is any form of alliance between two or more people who work together formally related to achieving a predetermined goal, within a bond within which there is one or several people called subordinates".

According to Newstrom and Davis (2002) that organizational behavior tends to be influenced by four factors as can be seen in Figure 1.

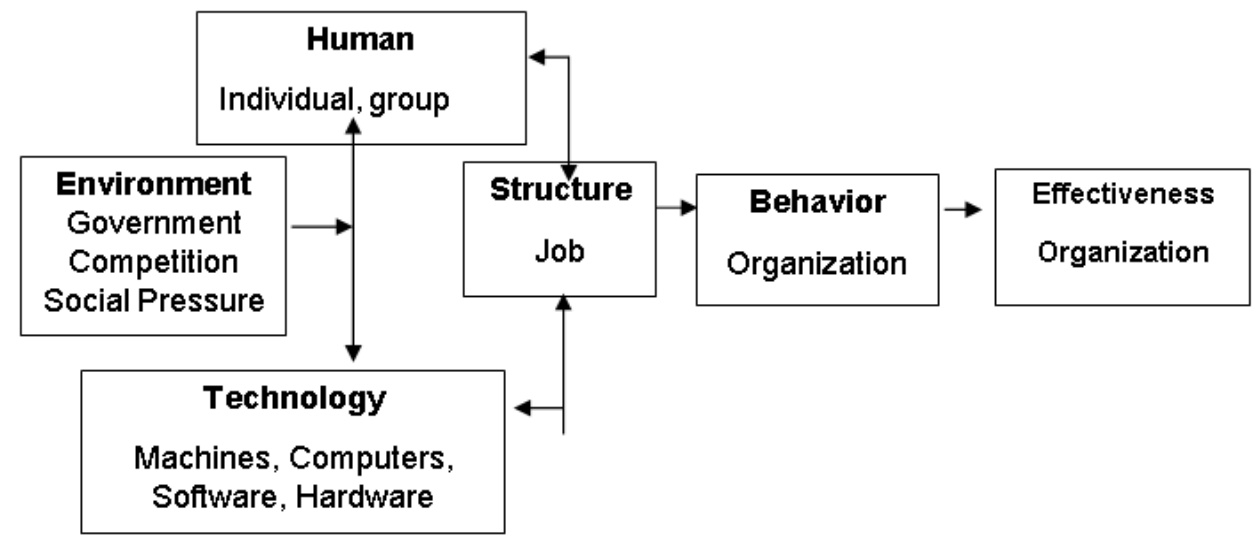

Figure 1. Factors Affecting Organizational Behavior Sources: Newstrom and Davis (2002)

\subsection{Organizational Culture}

According to Deal \& Kennedy (in Herbert, 2002: 16), "a cohesion of values, myths, heroes, and symbols that have come to mean a great deal to people who work there" Organizational Culture is values, myths, heroism, and the symbols used that become an advantage for working people.

Organizational culture is a system of shared meanings shared by members of the organization that distinguishes these organizations from other organizations. The characteristics of organizational culture according to (Sunyoto in Syardiansah, 2020) are: 1) Innovation and the courage to take risks, namely the extent to which employees are encouraged to be innovative and dare to take risks. 2) Attention to details / details, ie to what extent employees are expected to carry out accuracy / precision, analysis and attention to details. 3) Results orientation, which is the extent to which management is more focused on results rather than focusing on the techniques or processes used to achieve these results. 4) 
People orientation, i.e. the extent to which management decisions consider the effects of these results on the people in the organization. 5) Team orientation, which is the extent of the work activities of the organization on the team rather than individuals. 6) Aggressiveness / aggressiveness. that is to what extent people are aggressive and competitive rather than relaxed. 7) Stability, i.e. the extent to which the organization's activities emphasize maintaining the status quo as opposed to growth.

The mention of corporate culture is often exchanged with the term organizational culture, and in writing, the authors use these two terms alternately or together, this is adjusted to the references used, but the meaning of the two terms is the same. Regarding the understanding of organizational culture according to Edgar Schein in Ivancevich (2011: 44) are:

"A pattern of basic assumptions - created, discovered, or developed by certain groups when learning to deal with problems of external adaptation and internal integration - that has gone well enough to be considered valid and therefore, to be taught to new members as the correct way to perception, thinking, and feeling in connection with the problems they face."

\section{a. Typology of Organizational Culture} culture:

Harrison, Mc Kenna, et.al, in Turmudzi (2012: 79), divides four types of organizational

- Power Culture

This culture focuses a small number of leaders using more power in the way of governing.

- Role Culture

This culture has something to do with bureaucratic procedures, such as; organizational rules and role roles or specific positions in an organization.

- Support Culture

Support costs reflect the existence of a group or community that supports someone who is seeking integration and a set of shared values in an organization.

- Achievement Culture

Achievement culture is a reflection of the encouragement of individuals in the organization to carry out tasks in a professional and proportional manner in accordance with their respective job descriptions. .

\section{b. Organizational Values and Culture}

Organizational culture has been put forward as values, principles, traditions, and ways of working shared (shared) has grown rapidly along with the times and really really affect how an organization is run. (Robbins and Coulter, 2010: 63). According to Robbins: "Strong culture is a culture that instills core values in a strong and widely accepted way among employees who have a greater influence on employee behavior than weak cultures" (Robbins and Coulter, 2010: 64).

\section{c. Cultural Function}

Robert Kreitner and Angelo Kinicki in Tika (2010: 13) divide the four functions of organizational culture, namely:

- Provide organizational identity to employees.

- Facilitating collective commitment.

- Promoting social system stability.

- Forming behavior by helping managers feel their presence. 
Several studies of organizational culture have proven that cultural strength is not enough to ensure the success or failure of an organization / company. Furthermore, a culture that serves the organization well as a step that is considered good at one time, may be counterproductive in the next step.

\section{d. Dimensions of Organizational Culture}

According to Robbins (2001) cultural characteristics are as follows:

- Innovation and the courage to take risks (innovation and risk taking), which is the extent to which members of the organization are encouraged to innovate and dare to take risks that include patterns of ideas, forms of innovative work and risk taking.

- Attention to detail, namely the extent to which members of the organization are expected to show accuracy and detail and include the implementation of job descriptions, accuracy in work and corrective actions.

- Outcome Orientation ie the extent to which management focuses on results, including quality orientation, quantity orientation and work reports.

- People-oriented (People Orientation), namely the extent to which management decisions take into account the impact on members in the organization which includes work facilities, work environment, work assessment, rewards and sanctions and career development.

- Team oriented (Team Orientation), i.e. the extent to which work activities are organized around the team which includes emphasizing the importance of teamwork, clarity of teamwork, assessment of team performance.

- Aggressive (Aggressiveness) is the extent to which organizational members are encouraged to work hard, aggressively and competitively healthy, which includes stimulating initiative and a competitive atmosphere.

- Stability, namely the extent to which the organization's activities emphasize adjusting to the environmental changes that are encountered rather than maintained the status quo. Includes clear objectives, regulatory consistency and employee stability.

\subsection{Work Motivation}

According to Robbins (2010: 109) motivation refers to the process by which a person's efforts are energized, directed, and sustained towards achieving a goal. "This definition has 3 (three) key elements: energy, direction and perseverance.

According to Siagian (2002: 102) motivation is a driving force for someone to make the largest possible contribution for the success of an organization to achieve its goals. With the understanding that the achievement of organizational goals means also the personal goals of the members of the organization concerned are also met.

Workers do work expecting compensation to meet their personal needs and goals to realize their work performance. If someone has the motivation to achieve their personal goals, then they must improve performance. Increasing one's performance will improve organizational performance. Thus, increasing one's motivation, will improve the performance of individuals, groups, and organizations.

Motivation (motivation) in management is only intended for human resources in general and in particular subordinates. Motivation questions how to direct the power and potential of subordinates to be willing to work together productively to achieve and realize the specified goals. One of the important things that must be done by a leader is to provide motivation or encouragement to improve employee performance. 
Chung \& Megginson in Faustino Cardoso (2003: 177) states that "motivation is defined as goal directed behavior, it concerns the level of effort one exerts in pursuing a goal, it is closely rolated to employee satisfaction and job performance". (Motivation is formulated as a behavior aimed at the target, motivation is related to the level of effort done by someone in pursuing a goal, motivation is closely related to employee satisfaction and job performance). Motivation according to Greenberg and Baron (2003: 190) is a series of processes that arouse (direct), direct (direct), and maintain (maintain) human behavior toward achieving goals. Generating relates to the impetus behind the action, while maintaining or maintaining behavior relates to how long a person will continue to strive to achieve the goal.

\section{Research Methods}

This research uses descriptive and verification methods. The place of research was conducted at Sumut Bank of Sharia Unit in North Sumatera. Considering the nature of this research is descriptive and verification, the research method used is descriptive survey and explanatory survey method. The type of investigation in this research is causality, which is testing the causal relationship between independent variables, intervening variables, moderating variables and dependent variables. The unit of analysis in this study is the employees at the North Sumatra Syariah Unit Bank in North Sumatra.

\section{Discussion}

\subsection{Test Results of the Validity Instruments of Organizational Culture Variables}

Testing the validity of the organizational culture variables used as 21 statement items distributed to 150 samples. The results of testing the validity of organizational culture variables can be seen in Table 2 as follows:

Table 2. Test Results of Instrument Validity of Organizational Culture Variables

\begin{tabular}{|c|c|c|c|c|}
\hline Variable & Item Questions & r- critical & r-table & Information \\
\hline \multirow{17}{*}{$\begin{array}{l}\text { Organizational } \\
\text { Culture }\end{array}$} & 1 & 0.6790 & 0.300 & Valid \\
\hline & 2 & 0.7350 & 0.300 & Valid \\
\hline & 3 & 0.7633 & 0.300 & Valid \\
\hline & 4 & 0.8095 & 0.300 & Valid \\
\hline & 5 & 0.8019 & 0.300 & Valid \\
\hline & 6 & 0.7489 & 0.300 & Valid \\
\hline & 7 & 0.6603 & 0.300 & Valid \\
\hline & 8 & 0.8042 & 0.300 & Valid \\
\hline & 9 & 0.8257 & 0.300 & Valid \\
\hline & 10 & 0.7527 & 0.300 & Valid \\
\hline & 11 & 0.7608 & 0.300 & Valid \\
\hline & 12 & 0.7385 & 0.300 & Valid \\
\hline & 13 & 0.8173 & 0.300 & Valid \\
\hline & 14 & 0.7388 & 0.300 & Valid \\
\hline & 15 & 0.8046 & 0.300 & Valid \\
\hline & 16 & 0.7017 & 0.300 & Valid \\
\hline & 17 & 0.7031 & 0.300 & Valid \\
\hline
\end{tabular}




\begin{tabular}{|c|c|c|c|c|}
\hline \multirow{4}{*}{18} & 0.7654 & 0.300 & Valid \\
\cline { 2 - 4 } & 19 & 0.7381 & 0.300 & Valid \\
\cline { 2 - 4 } & 20 & 0.7028 & 0.300 & Valid \\
\cline { 2 - 4 } & 21 & 0.8231 & 0.300 & Valid \\
\hline
\end{tabular}

Based on Table 2 above, the questionnaire for organizational culture is known that all instruments have a value greater than 0.300 . The conclusions obtained indicate that all instruments on organizational culture variables are declared to be all valid, that is, they have good accuracy in measuring these variables.

\subsection{Employee Perceptions of Organizational Culture}

Organizational Culture is measured by 21 question items with 10 (ten) dimensions namely individual initiative, risk tolerance, organizational direction, integration, management support, supervision, self-identity, reward system, conflict tolerance, and communication patterns. The following are the results of a study of 21 question items raised to measure organizational culture variables. Based on the results of data collection that refers to the questionnaire, scores obtained range of data values for organizational culture variables represented by 21 question items for 150 Employees.

Table 3. Respondents' Responses to Organizational Culture

\begin{tabular}{|c|l|c|c|c|c|c|c|c|}
\hline \multirow{2}{*}{ No } & \multicolumn{1}{|c|}{ Statement } & \multicolumn{3}{|c|}{ Alternative Answers } & \multicolumn{2}{c|}{$\begin{array}{c}\text { Rata- } \\
\text { Rata }\end{array}$} & $\begin{array}{c}\text { Standar } \\
\text { Deviasi }\end{array}$ \\
\cline { 2 - 7 } 1 & VS1 & S1 & M & S & VS \\
\hline & $\begin{array}{l}\text { The condition of the } \\
\text { organization is able to build } \\
\text { employee initiative }\end{array}$ & 17 & 99 & 32 & 2 & 0 & 3,566 & 0,878 \\
\hline 2 & $\begin{array}{l}\text { The condition of the } \\
\text { organization is able to build } \\
\text { individual employee awareness }\end{array}$ & 27 & 86 & 37 & 0 & 0 & 2,279 & 0,892 \\
\hline 3 & $\begin{array}{l}\text { Organizational culture } \\
\text { conditions tolerate employee } \\
\text { risk }\end{array}$ & 35 & 79 & 31 & 5 & 0 & 3,227 & 0,918 \\
\hline 4 & $\begin{array}{l}\text { Organizational culture } \\
\text { conditions tolerate } \\
\text { organizational risk }\end{array}$ & 32 & 83 & 33 & 2 & 0 & 3,566 & 0,909 \\
\hline 5 & $\begin{array}{l}\text { Organizational culture supports } \\
\text { the vision of the organization }\end{array}$ & 37 & 83 & 29 & 1 & 0 & 3,800 & 0,904 \\
\hline 6 & $\begin{array}{l}\text { Culture supports the mission of } \\
\text { the organization }\end{array}$ & 40 & 77 & 30 & 3 & 0 & 3,421 & 0,915 \\
\hline 7 & $\begin{array}{l}\text { Culture supports organizational } \\
\text { goals }\end{array}$ & 40 & 75 & 32 & 3 & 0 & 3,421 & 0,916 \\
\hline 8 & $\begin{array}{l}\text { Culture integrates the functions } \\
\text { of organizational systems }\end{array}$ & 36 & 77 & 35 & 2 & 0 & 3,566 & 0,914 \\
\hline 9 & $\begin{array}{l}\text { Culture of integrating work } \\
\text { activities }\end{array}$ & 40 & 77 & 32 & 1 & 0 & 3,800 & 0,909 \\
\hline 10 & $\begin{array}{l}\text { Management supports the } \\
\text { strengthening of organizational } \\
\text { culture }\end{array}$ & 25 & 102 & 22 & 1 & 0 & 3,800 & 0,869 \\
\hline 11 & $\begin{array}{l}\text { Management supports the } \\
\text { preservation of organizational } \\
\text { culture }\end{array}$ & 31 & 87 & 31 & 1 & 0 & 3,800 & 0,900 \\
\hline
\end{tabular}




\begin{tabular}{|c|c|c|c|c|c|c|c|c|}
\hline 12 & $\begin{array}{l}\text { The ability of organizational } \\
\text { culture in implementing } \\
\text { supervision }\end{array}$ & 29 & 96 & 23 & 2 & 0 & 3,566 & 0,887 \\
\hline 13 & $\begin{array}{l}\text { The ability of organizational } \\
\text { culture in implementing } \\
\text { supervision }\end{array}$ & 32 & 88 & 28 & 2 & 0 & 3,566 & 0,902 \\
\hline 14 & $\begin{array}{l}\text { The ability of organizational } \\
\text { culture builds organizational } \\
\text { identity }\end{array}$ & 25 & 95 & 29 & 1 & 0 & 3,800 & 0,887 \\
\hline 15 & $\begin{array}{l}\text { Cultural support maintains } \\
\text { organizational identity }\end{array}$ & 37 & 83 & 29 & 1 & 0 & 3,800 & 0,904 \\
\hline 16 & $\begin{array}{l}\text { The ability of the organizational } \\
\text { culture supports the reward } \\
\text { system that is applied }\end{array}$ & 22 & 102 & 25 & 1 & 0 & 3,800 & 0,870 \\
\hline 17 & $\begin{array}{l}\text { Cultural support maintains a fair } \\
\text { reward system }\end{array}$ & 31 & 73 & 43 & 3 & 0 & 3,421 & 0,920 \\
\hline 18 & $\begin{array}{l}\text { The ability of organizational } \\
\text { culture to build a conducive } \\
\text { conflict }\end{array}$ & 20 & 94 & 30 & 6 & 0 & 3,154 & 0,898 \\
\hline 19 & $\begin{array}{l}\text { Cultural support maintains a } \\
\text { conflict system }\end{array}$ & 21 & 92 & 29 & 8 & 0 & 3,036 & 0,903 \\
\hline 20 & $\begin{array}{l}\text { The ability of organizational } \\
\text { culture to build vertical } \\
\text { communication }\end{array}$ & 26 & 82 & 41 & 1 & 0 & 3,800 & 0,905 \\
\hline 21 & $\begin{array}{l}\text { The ability of organizational } \\
\text { culture to build horizontal } \\
\text { communication }\end{array}$ & 39 & 76 & 32 & 3 & 0 & 3,421 & 0,916 \\
\hline & Average & \multicolumn{7}{|c|}{3,505} \\
\hline & Standard Deviation & \multicolumn{7}{|c|}{0,966} \\
\hline & Range & \multicolumn{3}{|c|}{2,539} & to & \multicolumn{3}{|c|}{4,471} \\
\hline & Category & \multicolumn{3}{|c|}{ Not Strong enough } & to & \multicolumn{3}{|c|}{ Very Strong } \\
\hline
\end{tabular}

Recapitulation of the results of respondents' answers on organizational culture has an average of 3.505 with a standard deviation of 0.966 expressed as being less robust to the very strong category, this indicates that the organizational culture in the North Sumatra Sharia Bank is still lacking, because employees still think the system used is not sharia but conventional, so there are cultural differences that are still not implemented by employees. Nevertheless employees always try to improve and adapt to sharia culture.

Judging from the largest average of 3,800 with the smallest standard deviation of 0.909 , it shows that the management indicators support the strengthening of organizational culture, meaning that management always enhances organizational culture as a support of corporate goals. In this case management has applied organizational culture to achieve better organizational goals. In addition, other indicators such as the ability of organizational culture to build vertical communication with an average value of 3,800 with a standard deviation of 0.905 .

\subsection{Analysis of Organizational Culture}

The importance of culture in supporting the success of work units according to Newstrom and Davis (2003), culture provides the identity of its employees, culture is also a source of stability and organizational continuity that provides a sense of security for 
employees and more importantly is culture helps stimulate employees to be enthusiastic about their work. Whereas the fundamental goal of culture is to develop complete human resources so that everyone is aware that they are in a relationship of the nature of the role as a supplier customer in communicating with others effectively and efficiently as well as encouraging.

Culture is a pattern of all material and behavioral arrangements adopted by society as a traditional way of solving the problems of its members, including all organized ways, norms of belief, implicit cultural values, and fundamental premises and is an order. The dimensions of organizational culture above provide an understanding that a strong culture also helps business performance because it creates an extraordinary level of motivation in employees. Values and behaviors shared together make people feel comfortable at work, a sense of commitment or loyalty makes people try harder, work is intrinsically valued, is involved in decision making and its participation is recognized.

Based on the results of the descriptive analysis obtained an average value of 3,505 with 0.966 standard deviations stated as not good to the very good category, this indicates that the organizational culture in the North Sumatra Islamic Bank is still not good, because employees still think the system used is not sharia but conventional, so there are cultural differences that are still not implemented by employees. Nevertheless employees always try to improve and adapt to sharia culture.

\subsection{Effect of Organizational Culture on Increasing Work Motivation}

Based on the results of research and data processing, it can be seen that organizational culture variables have a direct or indirect influence on the Improvement of Work Motivation. The direct effect is $6.81 \%$ while the indirect effect through Leadership (X1) is $5.77 \%$, the indirect effect through competence (X3) is $4.28 \%$ and the total effect is $16.86 \%$, meaning that Organizational Culture provides contributions in forming an increase in Work Motivation by $16.86 \%$ so that when organizational culture increases the Increase in Work Motivation increases by $16.86 \%$. This shows that organizational culture has a significant influence on the Increased Work Motivation of employees of the North Sumatra Bank Syariah Unit in North Sumatra.

Organizational culture is determined by the values that dominate the organization accepted by the majority of employees and the norms and beliefs of members of the general organization. According to Cameron \& Freman (in Gull 2012) employees who work under the Clan culture (friendly environment and friendly mentors) and Adhocracy (creative workplaces, visionaries and innovative leaders) are satisfied with their work.

This is consistent with the results of research conducted by McClelland, (2008) which states that there is a positive influence between the strength and direction of one's behavior on employee achievement motivation. Needs that drive motivation, namely: Need for achievement, need for affiliation, and need for power. Robert Kreitner and Angelo Kinicki, (2001), someone will be more motivated if the organization has a strong culture. In organizations need a strong culture, because a strong culture will have a greater influence on employee behavior. Thus there is an influence between organizational culture on the Increased Work Motivation of employees of the North Sumatra Bank Syariah Unit in North Sumatra. 


\section{Conclusion}

Organizational Culture on Increasing Employee Motivation in Sumut Bank of Sharia Unit, North Sumaterais perceived as less powerful to very strong. The highest average value on management indicators supports strengthening organizational culture, meaning that management always improves organizational culture as a support of the company's goals. In this case management has applied organizational culture to achieve better organizational goals. Even so, there are still some weaknesses in the indicators. Organizational conditions are able to build individual employee awareness, this cannot be done by the company because individual employees are unable to adapt to sharia-compliant cultures compared to conventional ones. The experts also agreed with the findings of the researchers, and suggested the bank must have a specific organizational culture in accordance with its mission.

\section{References}

Amstrong, Michael dan Murlis, Helen, 2003, "Reward Management" A Handbook Remuneration Strategy And Practice. Fourt Edition.

Daft, Richard L 2002,. Manajemen(Jilid 1, Edisike-5), Erlangga, Jakarta,

Dessler, Gary, 2006, ManajemenSumberDayaManusia, Terj. Edisike- 10 jilid 1, Indeks, Jakarta.

DidiTurmudzi, 2012, BudayaOrganisasi, Prisma Press, Bandung.

Kotter P. JhondanHeskett L. James, 2007, “Coorporate Culture and Performance”, Dampak Budaya Perusahaan terhadap Kinerja, Person Education Asia, Jakarta.

Mathis, Robert Ldan John H. Jacson, 2006, Human Resource Management (Manajemen Sumber Daya Manusia). Ed ke- 10, Salemba Empat, Jakarta.

Mondy R Wayne, 2008,“ Manajemen Sumber Daya Manusia” Edisi - 10 Jilid 2, Penerbit Erlangga, Jakarta.

Montana, Patrick J. \&Charnov Bruce H, 2008, Management (Fourth Edition), Barron's, New York.

Raymond A. Noe, Jhon R.H., Barry G. Patrick M.W, 2010, Manajemen Sumber Daya Manusia, Mencapai Keunggulan Bersaing. Buku 1. Edisi Keenam, Penerbit Salemba Empat, Jakarta.

Riani, Asri Laksmi, 2011,Perspektif Kompensasi. (cet. Ke-2), Yuma Pustaka, Surakarta.

Rivai, H. Veithzal dan Ella Jauvani Sagala., 2009. Manajemen Sumber Daya Manusia Untuk Perusahaan, PT. Raja Grafindo Persada, Jakarta.

Rivai, H. Veithzal, et. al, 2008, Performance Appraisal, Edisi ke- 2, PT. Raja Grafindo Persada, Jakarta.

Simamora, Henry, 2004, Manajemen Sumber Daya Manusia, STIE YKPN, Yogyakarta.

Soekarso,. 2010, Teori Kepemimpinan, Mitra Wacana Media, Jakarta.

Sutrisno, Edi. 2010,Budaya Organisasi, Kencana, Jakarta.

Sunyoto, Danang dan Burhanudin, 2011,Perilaku Organisasi, Caps, Yogyakarta.

Syardiansah. (2020). The Effect of Job Satisfaction and Organizational Culture on Employee Performance of the Royal Hotel in East Aceh District. Budapest International Research and Critics Institute-Journal (BIRCI-Journal). P. 849-857.

Tika, H. Moh. Pabundu, 2010, Budaya Organisasi dan Peningkatan Kinerja, Bumi Aksara, Jakarta.

Tjahjono, Herry, 2010, Culture Based Leadership, Kompas Gramedia, Jakarta.

Wijaya, Muksin. 2005. Kepemimpinan Transformasional di Sekolah dalam Meningkatkan Outcomes Peserta Didik, Jurnal Pendidikan Penabur No. 5/Th. IV/Desember 2005

Kusdi. 2008. Membangun Organisasi melalui Pendekatan Budaya. Universitas Brawijaya Malang 